\title{
Sexual maturity and sex determination in Strombus canarium Linnaeus, 1758 \\ (Gastropoda: Strombidae).
}

\begin{abstract}
The study was conducted at the Merambong Shoal, Johor Straits, Malaysia. Strombus canarium was the most abundant herbivorous mollusc within the study site, highly prized as seafood and contributes to the economics of the locals. Ontogenetic development of sex characters and sexual maturity were determined via logistic curve analysis, using shell-length and/or lip thickness as predictors. The minimum shell-length at which sex characters appeared was at $30 \mathrm{~mm}$ in males and $32 \mathrm{~mm}$ in females and both sexes can definitely be determined at more than $41 \mathrm{~mm}$ shell-length. The SX50 (probability of individuals can be sexed is 0.5 ) was at $38.33+0.41 \mathrm{~mm}$ for male and at $37.15+0.31 \mathrm{~mm}$ for female. The SL, (length at which the probability of individuals are matured is 0.5 ) was at $54.14+0.86 \mathrm{~mm}$ shell-lengths for males and at 58.51+1.02 nun shell-lengths for females. The LIP,, (lip thickness at which the probability of individuals are matured is 0.5 ) values on the other hand was about $0.69+0.0003$ and $0.80+0.014 \mathrm{~mm}$ for males and females respectively. The findings indicate that sexual dimorphisms occurred at very early stage in S. canarium life history
\end{abstract}

Keyword: Dog conch; Johor Straits; Malaysia; Sexual dimorphism; Logistic curve analysis. 